\title{
The housing policy nexus and people's responses to housing challenges in post-communist cities
}

This article explores major trends and patterns of change embedded in the overall process of economic, social and political transformation reshaping the urban challenges in eastern European cities. It reflects on important drivers of change such as efforts to create a market-based housing system and competitive housing markets in the post-communist urban world. The research draws muchneeded attention to an important set of urban and housing policy issues with broad implications for understanding the transition process in the region. It explores the multi-layered processes of market-based housing reforms (privatisation, deregulation and devolution) and their impact on the spatial transformation of urban housing markets in eastern European cities. The main argument, supported with empirical evidence from a number of eastern European cities, is that the impact of these most significant processes of urban change has created a mosaic of diverse urban challenges. Exploring these urban challenges through the housing lens sets the stage for a better understanding of urban social movements in eastern European cities and their dynamic realities. The article argues that the diverse role of urban social movements can be explained by reference to democratic traditions, practices and policy cultures in eastern European cities, and also to institutional structures and the capacity of nonmarket stakeholders. In some cases, stronger government and governance traditions since the political changes of the 1990s would allow non-government organisations to "voice" their concerns and be accepted as a legitimate partner in coalitions responding to urban challenges. In other cases, such capacity and institutional collaboration may be non-existent, leading to "exit" and abandonment of formal systems. In the first option, urban social movements have resurrected debates about gentrification and social segregation in housing estates and neighbourhoods previously insulated from the market, fighting for their "rights to the city". In the latter option, individuals and organisations have resorted to informal solutions to growing housing inequalities, poverty and exclusion reflected in the massive growth of informal settlements and the illegality of urban construction.

Key words: post-communist cities, housing policy, housing problems, individual and collective action 


\section{Introduction and research approach}

Following the political changes of 1989 , various reform initiatives were carried out in eastern Europe to transform the housing sector. Housing reforms were motivated by pressures to reduce budget deficits and to move away from macroregulation and direct subsidisation of the housing supply to a market-oriented housing sector (United Nations Economic Commission for Europe, 1997). The common challenge of establishing a market system needs to be understood in the context of the important economic, political and social differences between the countries of the region at the outset of transition. These substantial differences have an impact on countries' housing systems with significant manifestations related to housing quality, tenure structure, output levels and affordability (World Bank, 2006). Notwithstanding these differences, it is widely documented that housing under communism was a political priority and that considerable budget resources and state institutions were deployed to address persistent housing shortages (Pickvance et al., 1997). At the start of the transition, housing lost this privileged status, leading to massive withdrawal of the state from housing investment and direct provision of housing services.

This article explores major housing reforms and patterns of change embedded in the overall process of economic, social and political transformation of post-communist cities. The research draws much-needed attention to an important set of urban housing policy issues with wide implications for understanding the transition process in the region. It explores the multi-layered processes of market-based housing reforms (privatisation, deregulation and devolution) and their impact on major housing challenges in post-communist cities. The framework of the analysis offers research carried out in two separate streams (policy and spatial analysis) in a multi-disciplinary manner, focusing on the most significant housing challenges/outcomes in cities.

Despite a diverse pattern of transformation, it is argued that the main challenges related to market-based housing transformation have several principal dimensions: a) pervasive shortage of affordable housing reflecting drastic cuts in public support and deregulation of mortgage and housing markets; b) deteriorating housing quality associated with housing privatisation, growing inequality and reluctance to implement rent reforms and c) conflicts and growth of informal housing development associated with the institutional transformation in the housing sector. The exploration of these urban challenges through the housing lens sets the stage for a better understanding of housing movements in post-communist cities and their dynamic realities.
Previous housing movements and collective action under communism, if any, were mostly driven by concerns over access to housing and housing shortages (Pickvance, 2001). Long waiting lists and various privileges, abruptly abolished in the early 1990s, resulted in tent cities, street opposition and discontent articulated by special interest groups in the media. The shift to more democratic governance in the housing sector, coupled with political, economic and social reforms, has created a more diverse arena in which various interest groups (public, private and non-governmental) interact and pursue a particular course of action (Tsenkova \& French, 2011). Special interest groups and strategic alliances with industry, political parties, financial interests and donor organisations have emerged with different abilities to leverage public support, to "voice" their concerns and to influence policymaking and policy implementation.

The research draws on Albert Hirschman's (1970) seminal work introducing two alternatives for members of an organisation in the context of changing/declining quality of services: "exit" (withdrawal) or "voice" (attempt at improvement through a proposal for change). These concepts allow a new perspective on mobilising action and support related to housing problems. "Exit" could be interpreted as lack of engagement and participation in the formal housing system, leading to informality and evasion of responsibilities (rent arrears and disinvestment in housing maintenance) with longterm consequences. "Exit" and "voice" themselves represent a union between economic and political action, but the choices between the two could be issue-specific and dependent on the institutional context (Hirschman, 1970). "Exit" and "voice" also interact in unique, dynamic and sometimes unexpected ways; by providing greater opportunity for engagement and mobilisation of support, "exit" can be eliminated. The housing system is viewed as the arena for mobilisation of actors, institutions and networks responding to problems and challenges, but also pursuing their own agenda and specific interests.

Chris Pickvance (2001) introduced a model of responses to housing dissatisfaction that emphasises the importance of social structure and the institutional context. He reviews three types of responses: "inaction", or no attempt to improve its housing situation; "individual action", or do-it-yourself improvements, privatising an existing flat, investing and buying a new home; and "collective action", or formation of groups and associations to improve housing conditions, fight rent increases, protect owner's rights and so on. The literature on social movements focuses on collective action, whereas studies that explore individualist action use the public choice model (Olson, 1965). The premise is that a rational individual will not participate in collective action if benefits can be obtained by inaction as a free rider. The assumption is that different 
costs and benefits (social, economic and material) are clearly identified.

This article questions the ability of individuals to maximise the cost-benefit gap in the dynamic context of post-communist economic and social transformation. It underscores the importance of structural forces affecting decision-making and views the institutional and housing policy context as a critical determinant in shaping these choices. The conventional picture of a housing market in which rational consumers respond to market signals and act rationally to maximise benefits and to mobilise resources for collective action might not be an appropriate model applicable to post-communist cities. The argument advanced in this article is that the conditions might work against collective action, and that economic and political institutions in the housing policy arena might favour certain choices, or be unresponsive to feedback and individual preferences, which decreases the potential of collective action benefits (Jenkins, 1983; Morris \& Mueller, 1995). Lack of openness of central and local housing institutions and their limited ability to deliver and implement housing policies in some post-communist cities affects resource mobilisation and might steer responses towards individual action.

The research brings together individualist and collective action models of housing responses to map out a repertoire of "voice" and "exit" options in post-communist cities. The premise is that housing provides grounds for individual and collective interests and will generate a mix of responses, but the choice will depend on the social context, the housing policy and the operation of institutions and the extent to which they favour "voice" and "exit". The general hypothesis is that, in postcommunist countries with more transparent housing policies, well-developed non-government institutions and consistency in policy implementation, the ability to mobilise resources to act collectively to improve housing conditions might be greater. In contrast, where housing policy has not been systematically pursued, collective action might be more difficult due to systemic barriers, lack of housing management and financial institutions presenting obstacles to individual action, and so "exit" options might be more prevalent.

Although the diverse role of housing movements can be explained by reference to democratic traditions, practices and policy cultures in post-communist cities, institutional structures (see, e.g., Mavromatidis \& Mavromatidi, 2012) and the capacity of non-market stakeholders will also make a difference in the transition context. In some cases, stronger government and governance traditions since the political changes of the 1990 s would allow non-government organisations to "voice" their concerns and be accepted as a legitimate partner in coalitions responding to housing challenges. In other cases, such capacity and institutional collaboration may be non-existent, leading to "exit" and abandonment of formal systems. In the first option, housing movements and strategic alliances have mobilised public support for homeownership and resisted rent reforms, fighting for people's "housing rights". In the latter option, individuals and organisations have resorted to informal solutions to growing housing inequalities, poverty and exclusion, reflected in the massive growth of informal settlements and the illegality of urban construction. The research focuses on four major urban housing problems related to access to affordable housing (formal or informal homeownership) or subsidised rental, as well as the improvement of privatised housing, to identify a range of "voice" and "exit" options.

The methodology is based on content analysis of housing policies, quantitative comparative data and evidence from publicly available government reports, academic publications and housing market assessments. The analysis draws on comparative evaluations on the topic carried out by major international organisations and research institutes, as well as country-specific assessments of housing policy reforms. It incorporates housing indicators from officially published sources of information and international databases and input from fifteen key informant interviews with major housing policymakers and activists carried out in several post-communist cities in the last three years.

\section{Housing reforms on the political agenda}

Recognising that different points of departure had a considerable impact on choices and reform strategies, evaluations of housing policy in post-communist countries have acknowledged two uniform trends: a) housing policy has taken a back seat on the political agenda and b) a residual housing policy, often targeting specific housing measures and/or groups, has been introduced (Hegedüs et al., 1996; Struyk, 2000). The transition imperatives of structural reforms, private sector growth and fiscal deficits naturally crowded out efforts to maintain housing as an important element of the welfare state.

In general terms, all countries in the region focused their housing policy reforms on strengthening market forces and reducing state intervention in the housing system. Those policies in the first phase of the transition promoted deregulation of housing markets, increased the role of private sector institutions and reduced public expenditure. The reforms also involved the privatisation of public assets: public housing and state construction enterprises. The practical implementation of the reforms across countries, mirrored in their macroeconomic performance and prolonged recessions, resulted in collapsing housing output, runaway house price inflation and rapid growth 


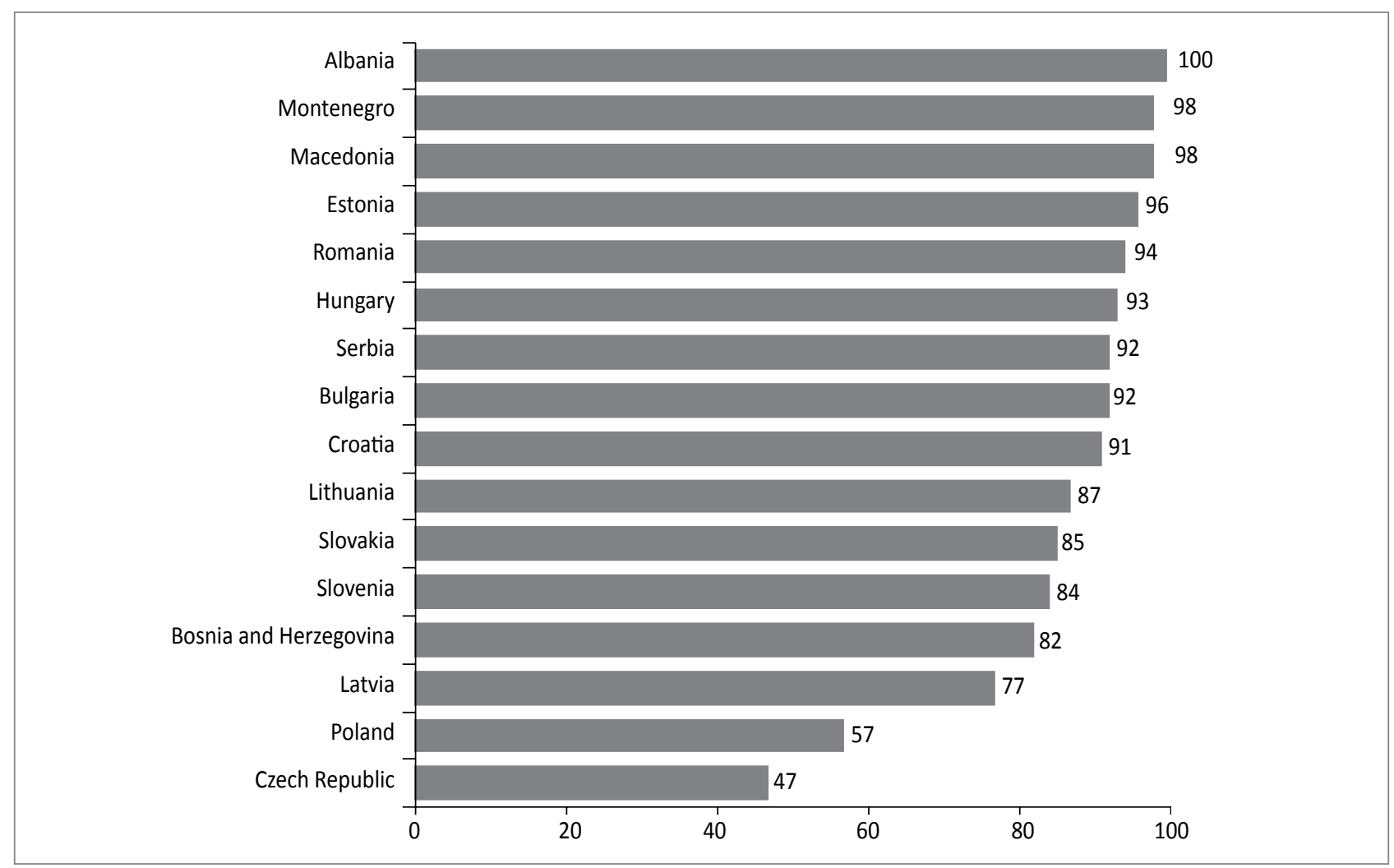

Figure 1: Homeownership in post-communist Europe, 2006 (source: United Nations Economic Commission for Europe, 2006).

in homeownership (United Nations Economic Commission for Europe, 1997). The elimination of extensive and universal housing subsidies was particularly successful in reducing the public deficit. Communist countries on average were spending over 5\% of their GDP on housing with another 5\% allocated to subsidise utility costs. Under the new fiscal austerity regime, housing subsidies across countries in the region were reduced to less than $1 \%$ of GDP in most cases (Tsenkova, 2009). Led by public expenditure considerations, housing policymakers rapidly deregulated the housing provision system, leaving the supply of housing services to the new market institutions with housing output by the private sector increasing to $90 \%$ of total output. Although such reforms had a long-term impact on the supply side, the privatisation of housing through "right to buy" policies dramatically transformed housing markets with long-term consequences for housing demand.

The privatisation of public housing in post-communist Europe involved the transfer of more than three million homes within the first four years of the transition. This was in effect a huge off-budget subsidy because apartments were transferred to sitting tenants for free, in exchange for vouchers or for symbolic payment. In countries where privatisation was delayed (Estonia, Latvia, Slovakia, the Czech Republic and Poland), it was completed in the second phase of the transition reforms and/ or left to the discretion of municipalities. Levels of homeownership across the region exceed $80 \%$, creating nations of home- owners over a very short period of time. In fact, some of the poorest countries exceed 95\% homeownership (see Figure 1). The second phase of housing reforms is far from uniform. Although housing is still not a political priority, housing reforms have proceeded through "trial and error", focusing on addressing housing market problems rather than strategic intervention (United Nations Economic Commission for Europe, 2006; Tsenkova, 2009). There have been limited attempts to launch more strategic interventions. All countries have housing action plans, strategies and a myriad of "stop-and-go" housing programmes, but implementation is limited and the commitment is inadequate (Palachin \& Shelburne, 2005; World Bank, 2005). ${ }^{[1]}$

Risking oversimplification, the most significant reform measures during the second phase (2000-2010) relate to: a) decentralisation and devolution in housing policy; b) development of an adequate institutional and financial framework and c) new subsidy programmes and rent reforms. Despite the economic and social hardships, it is interesting to note that there has not been a popular backlash against the housing policy reforms, even in countries where independence brought to the fore unresolved ethnic tensions, conflicts and war. Rather, the choices have been driven by efforts to sustain the liberalisation of housing markets and to ensure a supportive legal and institutional environment. The devolution of housing responsibilities to the local government level also contributed 
to the loss of political support. Local governments, particularly outside of capital cities, have limited ability to mobilise funds for capital-intensive housing programmes. Furthermore, capacity constraints, frequent political changes and unfunded mandates have become significant constraints for housing policy implementation at the local level (Donner, 2006).

Over the past decade, with respect to the development of an efficient legal and institutional framework for housing, two broad patterns have emerged. In more advanced countries, sustained macroeconomic stabilisation, consistent effort to provide an adequate legal framework and economic growth have laid the basis for the gradual development of the institutions that are necessary to support housing markets. This development has been shaped by both internal political and economic pressure for consistency in housing reforms on the one hand, and the strong incentives and guidance of European integration on the other (European Bank for Reconstruction and Development, 2009). In the less-advanced countries, progress in liberalisation and macroeconomic stabilisation has been slow and uneven. Moreover, the legal framework has been developed with considerable delays and its implementation has been jeopardised by structural weaknesses of the financial sector and limited capacity of state institutions to implement and enforce the legislation (European Commission, 2010). In some southeast European countries, the public sector has attempted legislative reforms, albeit with limited success. National strategies, action plans and programmes have often been sidetracked by political/electoral changes and budget deficits (Tsenkova, 2005). Furthermore, the sharp decline in living standards that has occurred has caused great stress and has undermined confidence in housing reforms, resulting in massive illegal construction and informal housing development (Leckie, 2002).

\section{Institutional reforms and the changing governance of housing}

The transition has marked an important institutional change from government to governance in housing. The new governance in housing goes beyond the formal authority and incorporates practices and performance by different institutions and entities that interact with government. These represent a variety of public, private and non-profit stakeholders involved in implementing public policies and programmes in the housing sector. Fiscal austerity and economic uncertainty have affected the operation of central and local governments in the region and their ability to formulate and effectively implement housing policies. The central governments overall are playing an enabling role in housing with major responsibilities centred on legislative reforms. In contrast, local governments have acquired important responsibilities related to new hous- ing programmes and management of existing public housing (Tsenkova, 2006).

Because the development of housing institutions is determined by path-dependency, it is not surprising that institutional change is inherently slow and an imbalance has arisen between creating markets and establishing appropriate supporting institutions. Further, the types of institutions that matter differ during the various stages of the process. For example, transforming the state role in housing requires more than its withdrawal from directing housing production and finance. It is also crucial that the state support markets by providing a transparent and effective legal system and sound investment climate to improve economic performance. Due to the special nature of housing, it also important that the state facilitate a socially efficient provision system, enhancing housing quality and affordability to alleviate the social costs of transition.

At the central level, the responsibility for housing policy is typically given to the ministries responsible for public works, construction and spatial planning (see Tsenkova, 2011). Financial ministries have the decisive role in housing policy and determine the allocation of resources for the sector, either in the state budget process or through transfers to local governments. In other words, the "housing ministries" typically do not control a large range of policy instruments and need to work with a number of other ministries to achieve real change (United Nations Economic Commission for Europe, 2003, 2006). Furthermore, staff at the central level is often limited to a handful of policy officials that rarely have the capacity to monitor existing programmes and cope with the constant amendments to the legal framework. Political instability and frequent changes in governance, particularly during the first phase of transition, led to different and often conflicting priorities, "stop-and-go" housing programmes and little effort to create strong and sustainable housing institutions at the central level (Tsenkova, 2009). New national housing agencies have been established in several countries to facilitate the implementation of housing policies and/or deal with specific housing problems. In some countries (Latvia and Lithuania), housing privatisation agencies have been reinvented in a new role. In Albania, Croatia, Moldova and Romania these agencies act as housing developers using budget resources, public land and donor funding to solve urgent housing problems (e.g., completion of unfinished housing, compensation of tenants in housing subject to restitution, etc.). Over time, some of these agencies have been abolished.

At the local level, the reform process in the region has emphasised decentralisation, deregulation and local autonomy. In the new fiscal reality, local authorities are seen as "crisis managers" charged with many responsibilities related to providing infra- 


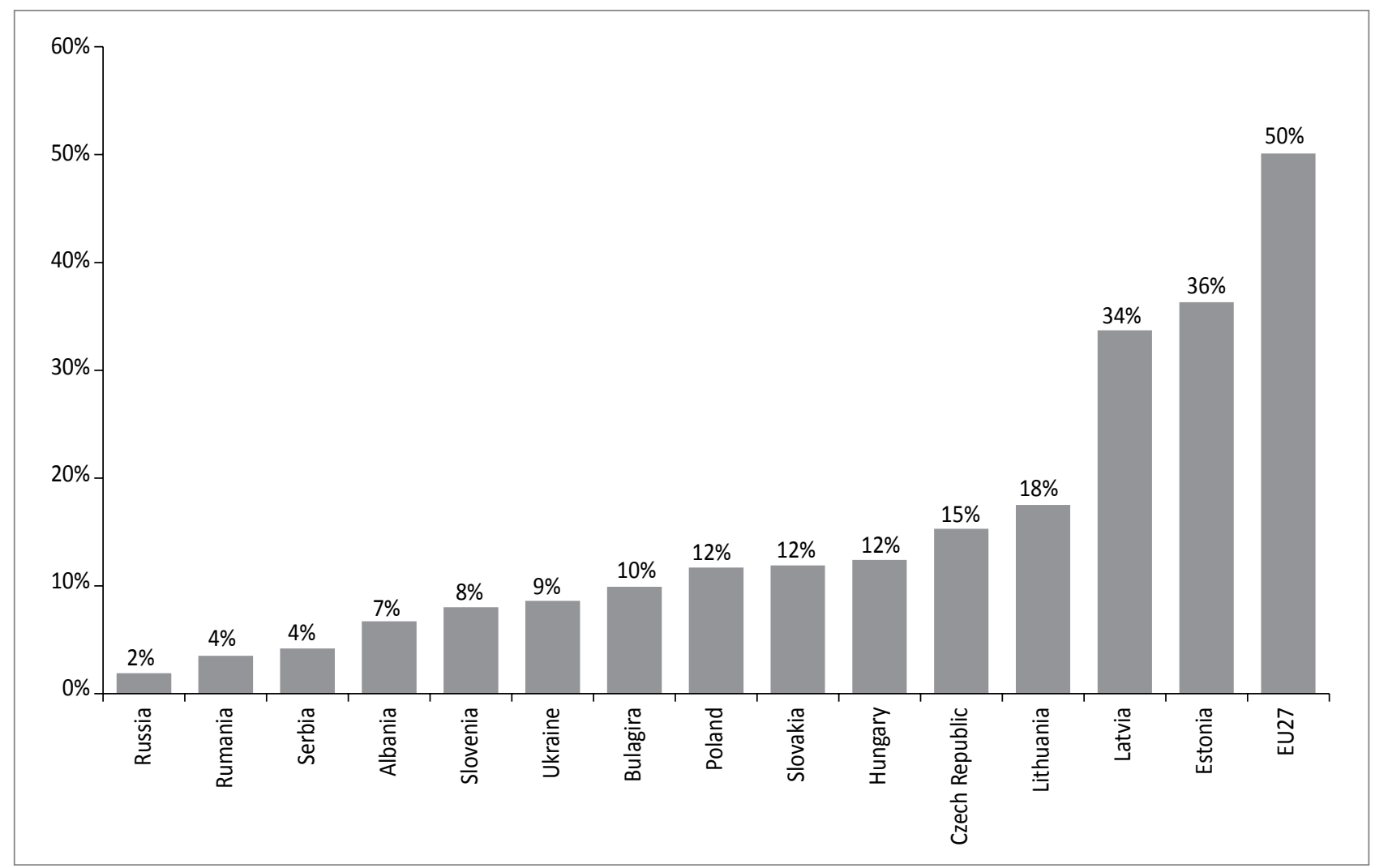

Figure 2: Mortgage lending as share of GDP in post-communist countries, 2009 (source: European Mortgage Federation, 2010).

structure and housing services, but without the corresponding resources to address those problems. ${ }^{[2]}$ Thus, the central government has shifted the conflicts in housing development to the local level. In addition to decentralisation, the degree of local government fragmentation has raised serious questions related to institutional capacity, coordination and the lack of economies of scale in managing public utilities (United Nations Economic Commission for Europe, 1997; World Bank, 2005). The local government administration has experienced constant cutbacks, problems with staff recruitment and political interference. It is not surprising that at the local level, and in smaller municipalities, the local bureaucracy is often criticised for its slow and inefficient responses to the needs of businesses and citizens' groups, red tape and alleged corruption.

Housing is typically a responsibility shared between the central and local governments, with the central level focusing primarily on legal issues and providing housing subsidies, whereas local governments have major responsibilities for implementing these programmes as well as for providing housing for the poor and disadvantaged. However, privatisation has left little, if any, public housing to respond to such needs. The residualisation of the public rental sector, coupled with a reluctance to implement systemic rent reforms, has led to poor quality of housing services. Despite different coping mechanisms, arrears in the sector are widespread and a lack of payment discipline is common (Hegedüs et al., 2013).

\section{The growth and diversity of housing market institutions}

Many private institutions are involved in producing, allocating and consuming housing, such as developers, landowners, financial institutions and market intermediaries. These new roles and responsibilities are associated with the new governance in housing, creating a dynamic and diverse mosaic of private and non-profit institutions and professional organisations. New actors have emerged - speculative homebuilders, real estate agents and private landlords - as a result of deregulation of land and housing finance markets. Although governments still identify the lack of housing finance as a main constraint on affordable housing provision, studies indicate that consumer lending has grown rapidly in the last five years, including mortgages and housing-related consumer loans (Hegedüs \& Struyk, 2006). Mortgage lending is dominated by large commercial banks, often with foreign ownership, offering international underwriting and servicing skills. ${ }^{[3]}$

The volume of mortgage lending across different countries, although much lower compared to the EU average, illustrates the relationship between housing reforms and the development of private institutions. Estonia and Latvia stand out with mortgage debt exceeding 30\% of GDP, with Lithuania and 


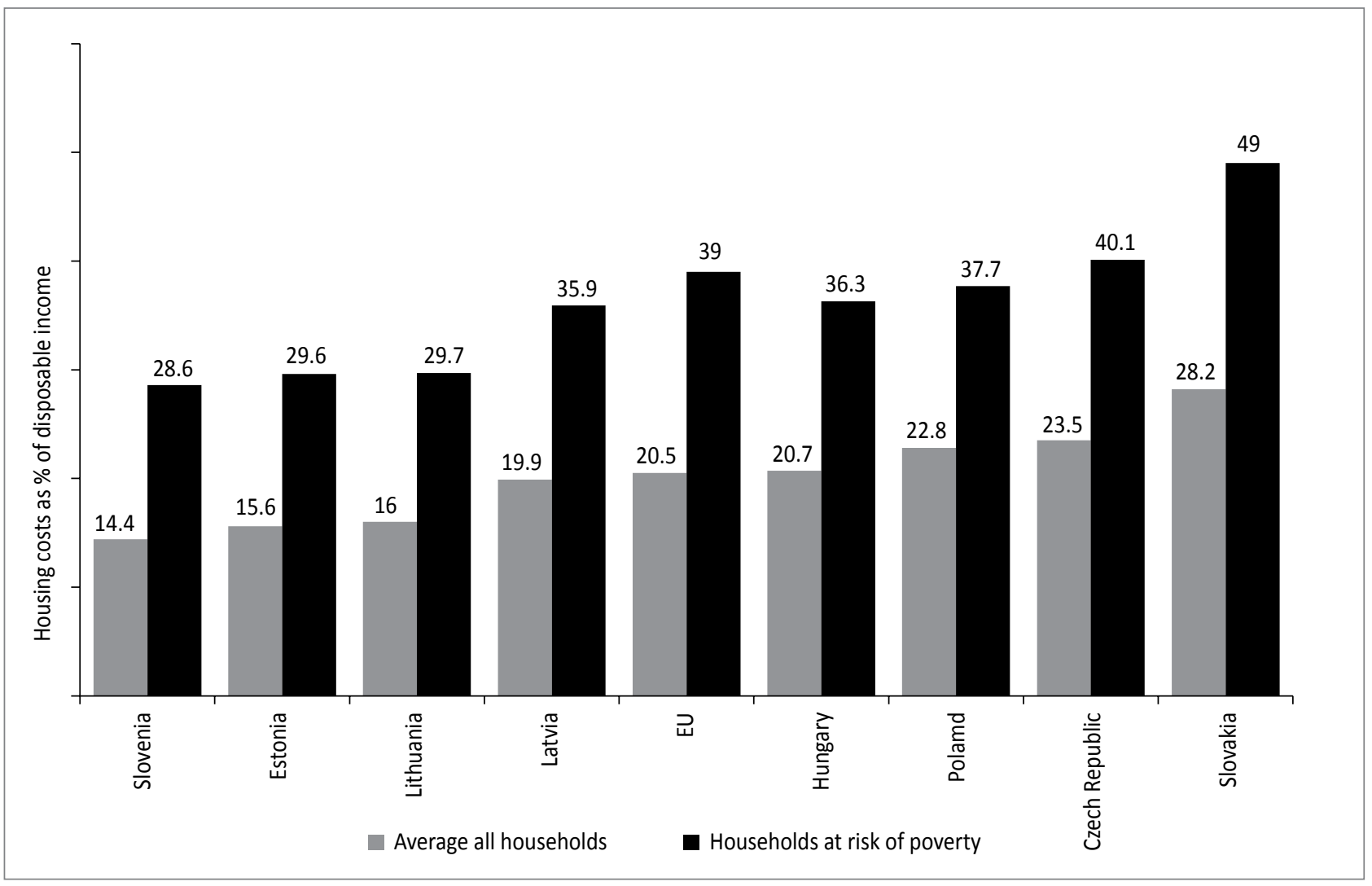

Figure 3: Housing costs as percentage of disposable income, 2007 (source: European Commission, 2010). Notes: EU refers to EU25; data based on EU-SILC Survey carried out in 2007.

the Czech Republic following at 17\% and 15\% (see Figure 2). Growth rates are indeed impressive for Albania, Serbia and Ukraine (over 85\%), albeit from a very low base. In addition to growth in mortgage lending, housing loans generally have been the most dynamic type of borrowing by households. Household loans have experienced a dramatic increase in recent years and reached 30\% of GDP in Croatia and 20\% in Estonia, Latvia and Hungary by 2004. Notwithstanding these positive developments in the volume of housing finance, borrowing is largely confined to more affluent groups, who can finance significant down payments and show evidence of regular incomes. Fiscal considerations, including subsidies and tax treatment of interest payments, also play a role in explaining cross-country differences in mortgage lending. The impact of a generous system of public subsidies in Hungary, Poland, Russia and the Czech Republic has been particularly notable. In other countries (Estonia and Serbia), the introduction of mortgage insurance has reduced the required down payment and enhanced households' borrowing capacity.

Non-government organisations (NGOs) in most of the countries in the region are at an early stage of development and require support to act as effective intermediaries between the public sector and civil society. They are generally limited in capacity and rely on international donors for funding. Rep- resentative bodies of owners or tenants at the national or local level are few, although there has been some attempt to involve NGOs in developing national housing policies. There are very few institutions dealing with housing research, surveys, data collection and policy evaluation. The early years of transition saw the formation of special interest groups, such as associations of private landlords in countries with restitution of nationalised housing, or some charitable groups catering to special-needs housing clients (the elderly, people with disabilities, etc.).

\section{The new subsidy regime, affordability and housing poverty}

Across post-communist Europe, the changing demographic and social composition of the population, growing social polarisation and income differentiation have influenced housing demand dynamics. On the one hand, this has led to a more diverse pattern of lifestyles and housing choices. People with more disposable income seek better living standards and move upmarket to more attractive environments. On the other hand, poverty manifests itself through the growing number of people on welfare, rising homelessness and a general shortage of affordable housing, particularly in urban areas. 
Housing policies have emphasised the importance of financial instruments - mortgage insurance, tax incentives and demand assistance to target groups - to facilitate access and choice. However, due to price inflation and higher rates of homeownership, the gap between income and entry costs has continued to increase for low-income households, making affordable housing of decent quality more difficult to obtain. Studies point out that rapid house price increases since 2005, despite improvements in mortgage lending, have excluded more than $80 \%$ of new households from the housing market (Registra, Analystas \& Imantra, 2005; Tsenkova, 2009). However, the large increase in house prices before the global financial crisis has been followed by an equally dramatic decline since 2008, potentially improving affordability. In Slovenia, for example, average prices rose by $14 \%$ from 2004 to 2006, whereas in Poland they rose by almost 20\% in 2007, and in Slovakia by $24 \%$. By mid-2009, however, prices fell in most of these countries - in Lithuania by 20\%, in Bulgaria by $22 \%$, in Estonia, by $31 \%$ and in Latvia by a staggering 60\% (European Mortgage Federation, 2010; for Slovenia see also Kušar, 2012; Sendi, 2010, 2013). ${ }^{[4]}$

Experts suggest that in most countries housing subsidies, excluding war reconstruction and refugee-related programmes, are less than 1\% of GDP (Puzanov, 2009; Tsenkova, 2009). Under the new subsidy regime, subsidies in the region have focused on making homeownership more affordable. Mortgage interest tax relief exists in Russia, Hungary and Poland. Housing subsidies are common in Croatia, the Czech Republic, Slovakia, Hungary and Poland. Part of these subsidies leak out to benefit mortgage and other providers in the housing systems, and raise the value of existing dwellings and development land (Palachin \& Shelburne, 2005). The prime intended beneficiaries, nonetheless, are the better-off owner-occupiers that can qualify for mortgage interest tax relief (Angel, 2000; Hegedüs \& Stryuk, 2006). The new subsidy schemes in postcommunist Europe have been criticised for being particularly inefficient in targeting households in need and for supporting the most affluent housing consumers (Tsenkova, 2009; Hegedüs et al., 2013).

The shift to a market-based housing system in which housing costs are borne by consumers has resulted in growing housing costs (a radical departure from communist times, when housing accounted for less than $4 \%$ of the household budget). Data on housing expenditure - housing, water, electricity and gas - show that it accounted for more than one-fifth of total household expenditure in 2007 (see Figure 3). The highest share is reported for Slovakia (28\%), followed by the Czech Republic (23.5\%). Levels of homeownership do not seem to be correlated with household expenditure on housing. Housing costs average $20 \%$ of disposable incomes in Latvia, $21 \%$ in
Hungary and $15.6 \%$ in Estonia, yet in all three countries just under $90 \%$ of people own their homes. Not surprisingly, housing costs are much higher for those at risk of poverty, reaching $40 \%$ in the Czech Republic and 49\% in Slovakia, a share much higher than the EU average (European Commission, 2010).

Affordability of housing remains the fastest-growing and most pervasive housing challenge in the region. Housing costs have increased with significant implications for access to adequate and affordable housing, particularly for low-income groups. Privatisation has alleviated the risk of poverty by providing mortgage-free housing. In practice, however, in countries where housing reforms are more advanced in shifting the burden of housing costs to the individual consumers, such costs in relation to disposable income are comparable and even higher than the EU25 average (European Commission, 2010). For most of these countries, utility and heating expenses account for the bulk of the housing costs and a small portion for rent and mortgage payments. The situation appears to be more problematic for single-person and single-parent households in urban areas, where higher prices for housing and concentration of poverty create cumulative disadvantages (European Commission, 2010).

Homeownership has grown steadily in most countries, particularly as a result of privatisation policies. Although some of this housing might actually function as private rental, responding to pressures from migration and labour market adjustment, the tenure structure is quite polarised, leaving a small and residual sector of publicly owned housing with a social purpose. Available data on residents in different types of tenure in several countries highlight some important differences with respect to affordability and choice (see Figure 4). First, a large segment of homeowners live in mortgage-free housing (in the Czech Republic, Latvia, Poland, Russia and Ukraine this share tends to be higher than 20\%). In all of these countries, housing represents a large proportion of household wealth because house prices have risen faster than earnings. Second, mortgage debt has also risen sharply in relation to household income, especially in Estonia and Hungary, where homeowners with mortgages are close to $15 \%$ of the population. Despite this being almost half of the $\mathrm{EU}$ average (27\%), the recession is likely to increase the number of people unable to afford mortgage or rent payments, as well as the number of evictions and repossessions in these countries. Homeowners with mortgages also tend to be higher in the Czech Republic and Lithuania, corresponding to better development of mortgage markets. Third, a smaller share of the population lives in subsidised or market rent accommodation compared to the EU average, with the Czech Republic being a notable exception. People living in rent-free housing also comprise a much more significant portion in half of the countries, with Poland having 


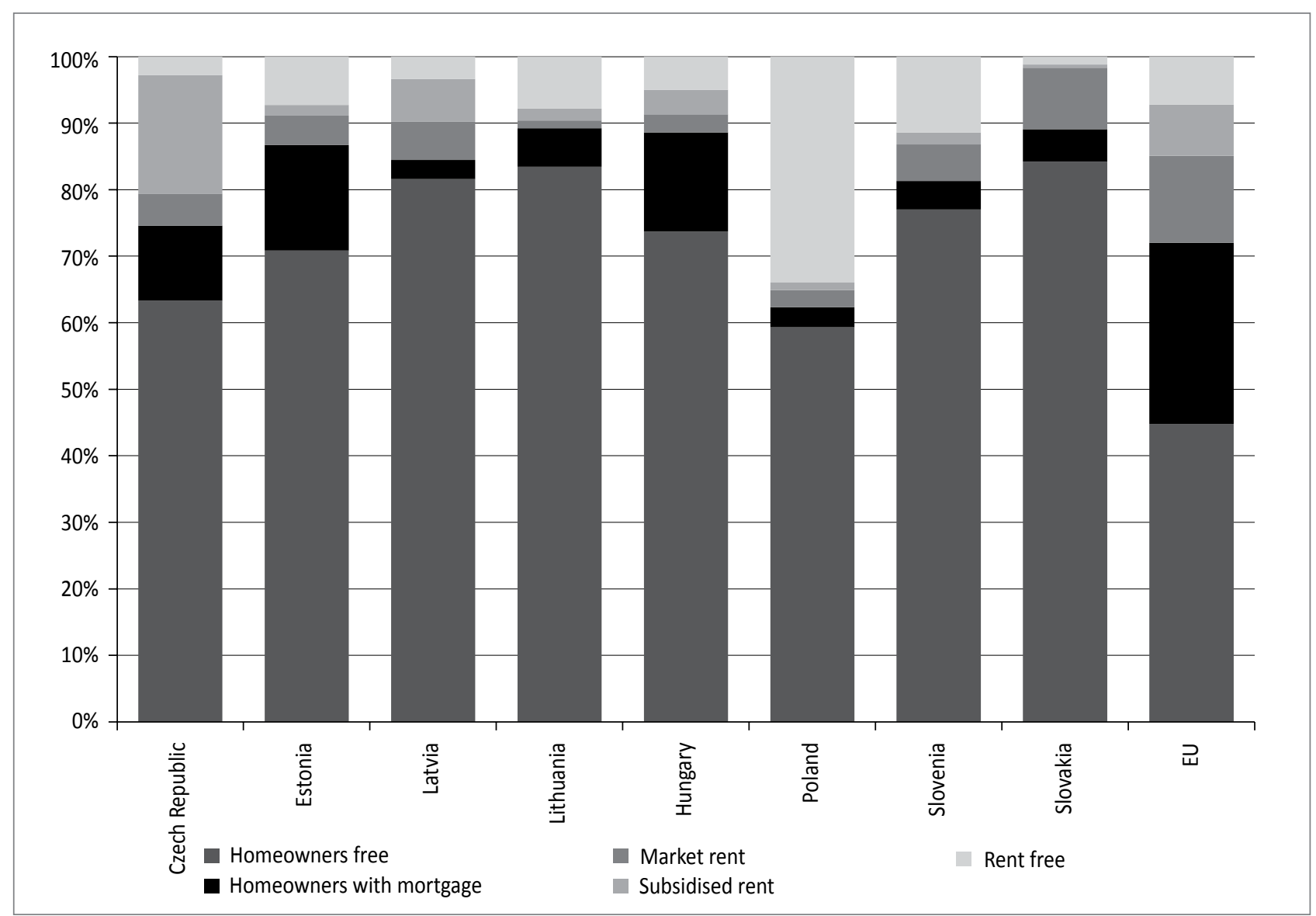

Figure 4: Division of population by housing tenure in select countries, 2007 (source: European Commission, 2010). Notes: EU refers to EU25; data based on EU-SILC Survey carried out in 2007.

almost $30 \%$ of people in such accommodation. In some cases, rent-free housing is tied to the workplace, and in other cases public rental housing tends to function as a safety net for poor households with zero rent. The proportion of tenants living in subsidised housing in the Czech Republic (18\%) is much higher than the EU average, followed by Latvia (11\%). Renters in subsidised housing have their rents subsidised by the state, local authorities or housing associations without necessarily accounting for income differences.

\section{Mobilising resistance against rent reforms: voices legitimising housing inequality}

Social or non-profit rental housing is owned by local governments or social housing providers. Its share is significant in several countries (Poland and the Czech Republic), but is declining gradually through continuing transfers to sitting tenants (Tsenkova \& Turner, 2004; World Bank, 2005). In most transition countries, social housing is not really defined in the legislation; however, public rental housing gradually assumes this function. Public housing is owned by local governments and is concentrated in urban areas. It is often funded through municipal or state/public enterprise funds and managed by municipal maintenance companies, which collect rents and handle tenant agreements. Rents are controlled and determined at the local level with some direction from the central government (Hegedüs et al., 2013).

After mass privatisation, local authorities were left with the worst housing stock in a poor state of repair and with the poorest tenants. Thus it is not surprising that in countries such as Slovakia and Latvia social housing is used as a safety net and rents are below cost-recovery levels with a limited number of tenants receiving housing allowances. ${ }^{[5]}$ However, in other countries where the sector is relatively large (Poland, Slovenia and the Czech Republic), it is home to a diverse social and income group, and so across the board uniform rent control legitimises existing housing inequalities and deprives the sector of much-needed rent revenue. For example, in the Czech Republic, where social rented housing is close to $20 \%$ of the stock, rents are less than $25 \%$ of the market rents (interview data, June 2011). The sector is home to $10 \%$ of the most affluent households. In Warsaw, rents in public housing are 5 to $10 \%$ of market rents, and the municipality is expected to cover the difference (interview data, July 2012). Rent reform in the Czech Republic and Poland has been delayed for decades due 
to successful mobilisation of tenant advocacy groups, NGOs and urban activists that fight to keep the rent control policy. The success of these effort might be attributed to the reluctance of local governments to confront the problem and the lack of institutional capacity to implement demand-based support assisting the poor and socially vulnerable (interview data, June 2011). Public housing is maintained by municipal maintenance firms at regulated costs well below the required levels to improve the quality of multifamily housing. Without central or local government subsidies, and poor collection of regular maintenance charges from owners, housing maintenance is significantly underfunded; in some countries the fees cover only 20 to $40 \%$ of the costs and barely cover emergency repairs (Gruis et al., 2009).

Although affordability constraints have grown, less social housing has been provided for low-income households. With slim chances for a significant expansion of state subsidies, the prospects for a meaningful reduction in the number of households with growing affordability problems in large urban centres are dismal. Although many of the projects aim at private or non-profit sector involvement, without capital subsidies to fill the gap between what low-income renters can pay and the rents needed to cover development costs, programmes cannot adequately serve the poor. Furthermore, the urban poor are not particularly vocal in local politics and often resort to "exit" options (interview data, July 2012). In this context, it is not surprising that very little new social housing has been provided in the region. Poland is a notable exception in the region, with an experimental limited-profit housing sector since 1995. The Polish housing associations (Towarzystwa Budownictwa Spotecznego, TBS) account for 5 to $7 \%$ of the housing output and rely heavily on preferential loans and subsidised access to land ${ }^{[6]}$ In several countries (Poland, the Czech Republic, Romania and Slovakia) social housing accounts for less than $10 \%$ of housing completions, whereas in other countries (Albania, Macedonia and Hungary) new small-scale social housing programmes for marginalised groups have been initiated since 2002. In addition to government funding, the construction of social housing is supported by the Council of Europe Bank through the provision of low-cost loans guaranteed by central governments. Unfortunately, all of these programmes, including the non-profit model in Poland, have been abandoned in the last two years as a result of austerity measures (interview data, July 2012).

\section{Mobilising fiscal support for homeowners: voices for regressive subsidies}

Despite the generic subsidy cutbacks during the transition, industry groups, financial institutions and various loosely for- mulated alliances have managed to rally political support for a variety of "stop and go" subsidy programmes to facilitate access to homeownership. The mix is complicated to evaluate because there is no systematic assessment of different government programmes (central or local) in terms of their efficiency (costs), targeting and effectiveness (outreach). Most of the support aims at homeowners providing a combination of public provision and demand-based assistance (grants, interest subsidies and tax incentives). Romania, Hungary, Poland, Slovakia and the Czech Republic have the most comprehensive housing programmes, whereas in Bulgaria and Macedonia housing has almost disappeared from the policy agenda in the last fifteen years. Other countries such as Albania, Moldova, Azerbaijan and Georgia are grappling with major economic difficulties, which reduce fiscal support to a limited set of policy measures with inefficient targeting.

The "trial and error" approach to various subsidy schemes has been plagued by populist policies, lack of political sustainability and inability to establish sound and transparent fiscal policies (Struyk, 2000; Tsenkova, 2009). Hungary, Estonia and Poland, for example, have experimented with a variety of demand- and supply-side subsidies to increase housing investment in new construction and renovation with constant adjustments in the level of subsidy, interest rates and loan amounts. ${ }^{[7]}$ Although there has been an attempt to reduce the commitment of governments through state provision of housing, an overwhelming majority of the countries still maintain these types of programmes. ${ }^{[8]}$ Similarly, a large number of countries have grants and subsidies for homeowners with a mix of programmes assisting war reconstruction (Bosnia and Herzegovina, Croatia and Kosovo) and subsidies to purchase or renovate housing through contract saving schemes (Slovakia, the Czech Republic and Romania). Tax incentives for homeowners are applied in Romania, Poland, Hungary, Russia and Croatia.

In most cases, these regressive subsidies support homeowners in higher income brackets, whereas very little is allocated for new provision of rental housing and for housing allowances. Demand-based subsidies to low-income renters have failed to keep pace with rising housing costs. In most transition countries such assistance is non-existent and, where it has been launched (e.g., the Czech Republic, Poland, Romania, Estonia and Latvia), it reaches a small number of households and is grossly inadequate (European Commission, 2010).

\section{Mobilising support for investment in privatised housing: voice and exit}

In the privatisation aftermath, the management and rehabilitation of multifamily housing is potentially one of the largest prob- 
lems facing post-communist cities because failure to improve its quality will result in massive structural problems in more than $40 \%$ of the urban housing stock. ${ }^{[9]}$ Addressing the problems in privatised multifamily housing is related to two significant challenges: institutional and financial (Tsenkova, 2012a). It also illustrates the difficulties in mobilising owners' support for investing in their own housing assets. Essentially, two alternatives emerge. In countries where the legal framework is more effective and governments leverage private investment through subsidised programmes, new institutional entities (homeowners associations) are taking charge and effective control over the management of their collective assets. Progress is difficult and the voices of these new alliances (owners' associations, industry, banks and NGOs) have gradually improved the available housing programmes and made them more effective (interview data, June 2010, 2011). These are small gains that certainly depend on the local initiative and the social mix in each homeowners association. In most of the cases, however, owners have taken the "exit" option, either improving their own housing space but opting out of collective action, or passively withdrawing from any engagement due to social stress, poverty or simple disengagement from any responsibilities.

The legal framework for housing privatisation of multi-family housing is also critical in shaping these responses. The forerunners in privatisation (Moldova, Lithuania and Albania) were among the first countries to introduce legislation in 1991, but the legal acts governing the management of common properties were introduced a decade later. In most cases, the legal response was reactive rather than proactive, with the Czech Republic being a notable exception. In this case, the establishment of homeowners associations (condominiums) was a requirement for transferring the building and individual privatisation of apartments was not allowed. In most of the other countries, the legislation has failed to impose in reality an obligation to take responsibility for buildings and common areas, and homeowners associations exist in less than $20 \%$ of the privatised housing (interview data, July 2012). Furthermore, the accelerated privatisation often transferred ownership of the apartments while municipalities were left with the ownership of buildings, land and common areas. Mixed ownership is an issue in countries such as Latvia, Russia and the Czech Republic, where owners and tenants live in the same building (Gruis et al., 2009).

In addition to institutional and legal constraints, the collective form of privatised housing from the past has a critical effect on housing management and quality. Every observer in the region concludes that the deterioration process in parts of the urban stock has reached a critical stage. Panel technologies, which featured prominently in Russia, Lithuania, Bulgaria, Moldova and Romania, resulted in large-scale developments
Box 1: Housing rehabilitation programmes in Hungary and the Czech Republic

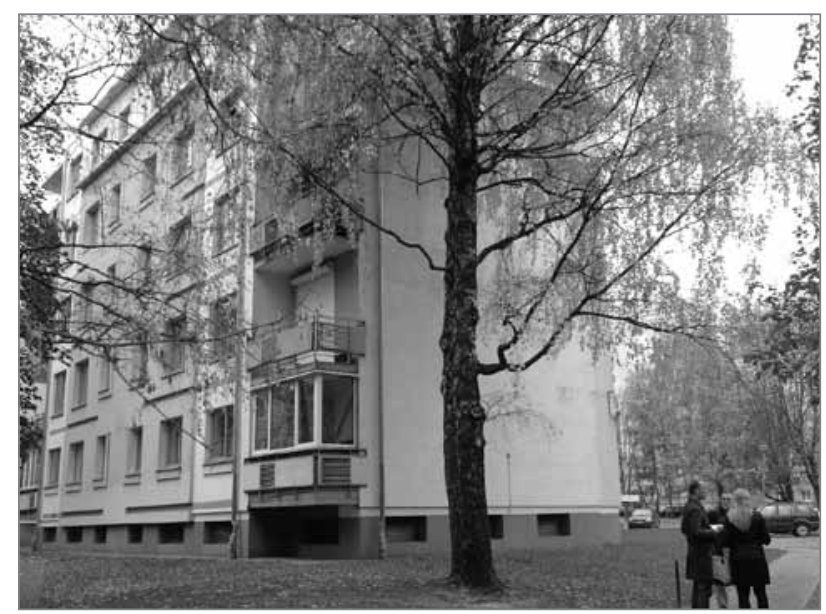

In Hungary, the Széchenyi Plan of 2001 aimed to mobilise the nation's resources to improve the energy efficiency of housing estates built from pre-fabricated elements and owner-occupied single-family housing. Two programmes with a total budget of EUR 55 million provided a $30 \%$ subsidy towards the cost of energy efficiency retrofits and quality improvements. The subsidy leveraged substantial private investment and targeted the improvement of energy efficiency parameters of the buildings (insulation, heating, individual heating regulation facilities, and replacement of doors and windows).

The Czech Republic offers another positive example, despite the small outreach of its panel renovation programmes. The government has launched two programmes since 2001 aimed at rehabilitating multiapartment units and regenerating panel housing estates. Low-cost loans and subsidies fund up to $70 \%$ of the costs, and homeowners, cooperatives and municipalities provide matching funds. Most of the borrowers ( 85 to 90\%) are housing cooperatives and homeowners associations. So far the programmes have assisted the rehabilitation and energy-efficient retrofitting of less than $8 \%$ of the panel housing.

Source: Tsenkova (2012b)

with demanding requirements for their housing management. Although most urban multi-apartment housing is less than forty years old, its initial quality was not very high. Subsequently, inadequate investment in maintenance as well as deferred capital repairs have aggravated the technical problems with leaking roofs, obsolete installations, faulty elevators and poor wall insulation (United Nations Economic Commission for Europe, 2006; Gruis et al., 2010). The energy efficiency of the stock is very low and, with the deregulation of energy costs and the elimination of subsidies, households were faced with disproportionately high costs for heating, crowding out the ability to invest in housing improvements. ${ }^{[10]}$

Studies indicate that, despite the effort to establish an adequate legal framework for the operation of homeowners associations, new owners are reluctant to assume these responsibilities. Municipal maintenance companies still manage privatised housing 

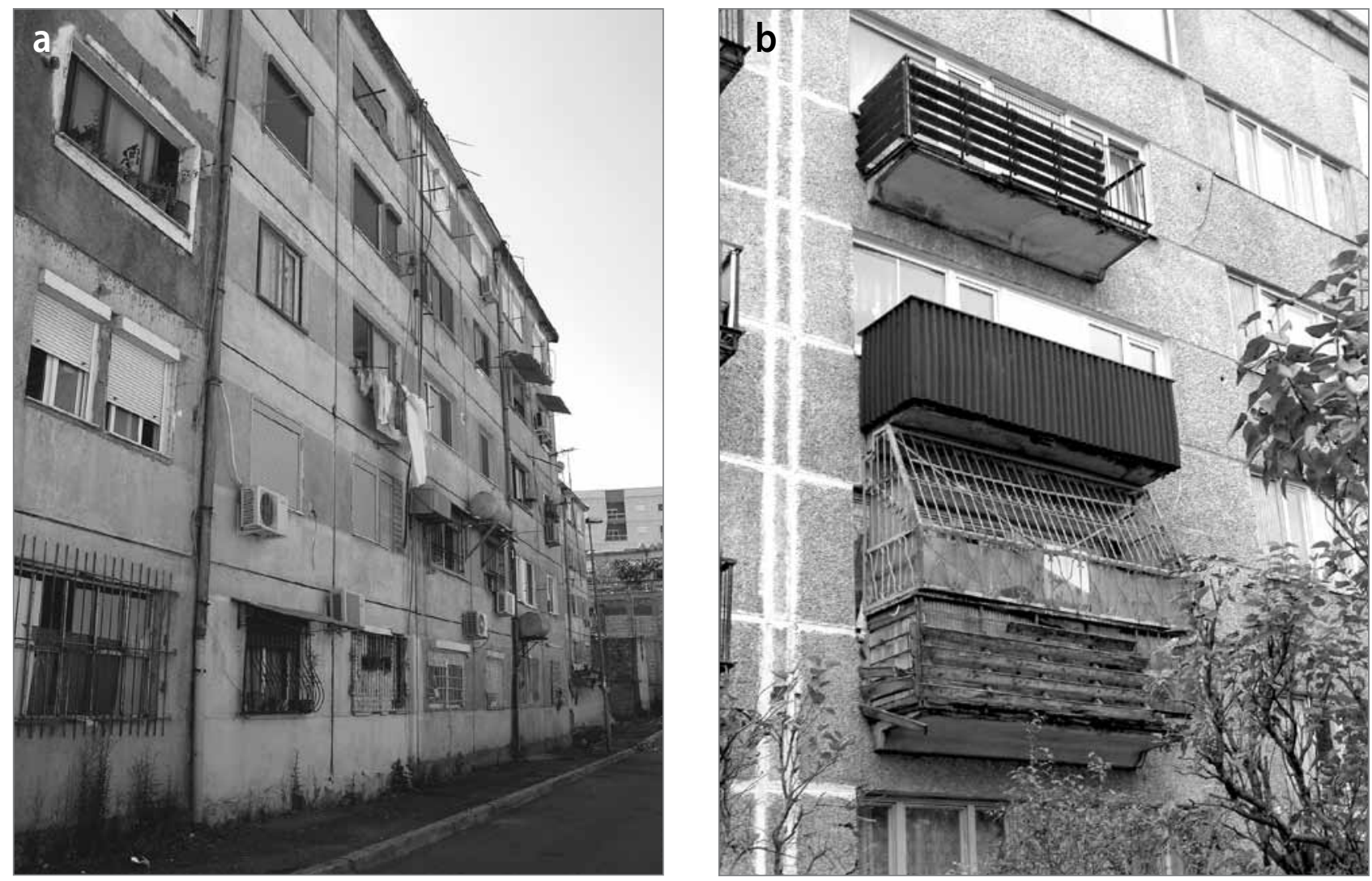

Figure 5: a) Lack of collective action in multifamily housing by homeowners in Sofia and b) by tenants that privatised their flats a decade ago in Riga (photo: Sasha Tsenkova).

in a number of post-communist cities under contractual obligations at locally controlled prices. The fees for maintenance are too low, and so households do not pay the true costs for services. In addition, the level of housing-related services (water, energy services, district heating, garbage collection and waste management) has declined because of subsidy cuts, rapidly escalating costs and utility payment arrears. With the "exit" options being dominant, housing poverty and deprivation is widely manifested in the housing estates of the region. ${ }^{[11]}$

Lack of adequate financing is considered a major constraint. Many of the owners tend to be asset rich but income poor and are unable to cover the costs of major repairs (interview data, 2011). In most of the cases, multi-apartment buildings have reached this critical stage in the lifecycle assessment where a major infusion of capital will be needed to bring them back to standards. The buildings are poor quality and the current stream of revenues does not ensure sufficient funds for renovation and improvement of the building envelope (roof, foundation, etc.) and energy efficiency retrofits. In addition to the institutional challenges for collective action mobilisation, it is difficult to borrow funds for major improvements. Banks often request that individual owners sign a mortgage or a loan contract, which makes the process extremely cumbersome and costly (interview data, May 2010). Very few countries have launched experimental programmes to assist this process (e.g. Latvia, Lithuania, Hungary, the Czech Republic and Slovakia).

\section{Growth of informal housing: exit}

A new pattern of informal housing provision has emerged in a number of post-communist cities. These informal developments are often substandard, consisting of makeshift shacks serving as the home of Roma communities, refugees or recent migrants to the city (see Figure 6). ${ }^{[12]}$ In countries affected by internal conflicts, a high share of internally displaced people has triggered a housing crisis in host cities. Almost seven million people have become refugees or internally displaced in the last decade (Internal Displacement Monitoring Centre, 2007). These are indeed the new faces of urban poverty associated with housing deprivation and social exclusion. They often inhabit tent camps, temporary housing, old railway cars and buses clustered in unsafe and impoverished areas. Such informal housing has emerged on the outskirts of Podgorica, Belgrade and Sarajevo (interview data, May 2010). Informal settlements in post-communist southeast Europe have grown significantly to shape large parts of the urban landscape. Although there are different levels of informality, residents lack secure, basic infrastructure, often squat on public or private land and occupy illegal buildings (Vienna Declaration, 2004). Informality in 


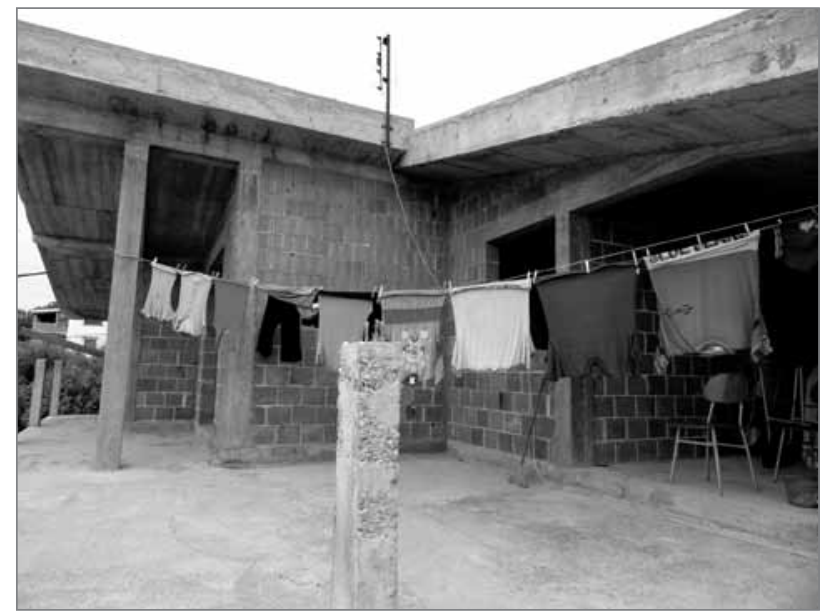

Figure 6: Roma informal settlement in Tirana (photo: Sasha Tsenkova).

many parts of the region evokes images of poverty, exclusion and despair, but there are certainly examples that deviate from this norm. Despite the lack of tenure security, some developments have good-quality structures built (albeit illegally) by affluent residents and speculative homebuilders. The evolution of informal settlements is diverse in terms of standards (from slums to luxurious residences), location (from suburbs to city cores and protected areas) and size (from several small units to settlements for over 50,000 residents). Apart from addressing urgent housing needs, illegal investments in housing and real estate represent an exit from the normal housing provision system and have been used by many households as a "shield" against instability and hyperinflation.

Squatter settlements, built on illegally occupied land, usually through self-help, often in peri-urban areas, have become home for hundreds of thousands of people. For example, in Albania informal housing settlements contain up to a quarter of the population in major cities and $40 \%$ of the built-up area (see, e.g., Stefanovska \& Koželj, 2012). In Macedonia, they are home to $11 \%$ of the population in the largest cities. In Belgrade, informal settlements occupy up to $40 \%$ of the residential area (Tsenkova, 2010, 2012b).

Some informal settlements do not necessarily comprise poorquality, under-serviced housing. Mixed-use developments built through self-help on illegal subdivisions of agricultural land are widespread; land is developed without official planning permission and the standard of infrastructure is low. In some cases the process is commodified and used by builders to provide housing to middle-class families at below-market prices (interview data, July 2012). Residents build private roads, selffinance connections to electricity and water supply, and use various tactics to negotiate legalisation. Informal settlements include housing, tourism and retail services, as the examples from Montenegro illustrate (see Figure 7). Real estate is traded

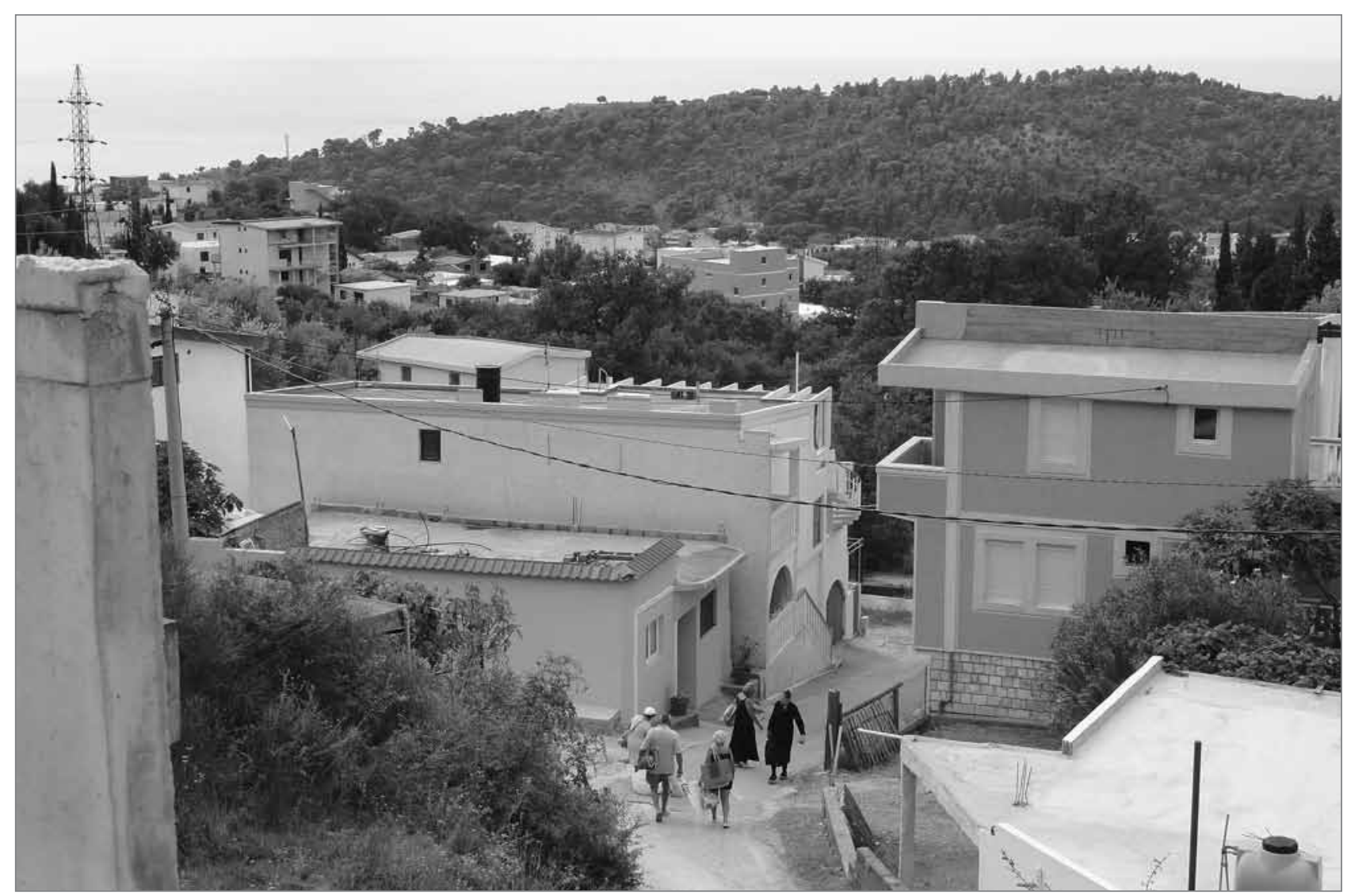

Figure 7: Informal hotels and mixed-use development in Bar, Montenegro (photo: Sasha Tsenkova). 
without registration in the cadastre, owners do not pay property taxes and economic activities (tourism and retail) remain informal (interview data, June 2011).

Over time, de facto legality is implied by the fact that the settlements are not demolished, and some infrastructure, such as water, electricity and sewer, is provided by local municipalities. The informal settlements in the post-communist cities of southeast Europe are a distinct manifestation of the postcommunist systemic transformation process, exacerbated by the lack of affordable housing, effective urban planning and public support for low-income housing (Gabriel, 2007). The "exit" option, through informal land acquisitions, subdivisions and other self-help solutions, is perhaps a natural coping mechanism for poor migrants and refugees, but has been adopted by many others, including developers.

\section{Conclusion:"voice" and "exit"}

Housing reform efforts emphasised the importance of housing markets, privatisation and private sector provision. The direction of change in all countries is similar, although significant variations exist. Reforms have proceeded via "trial and error", promoting devolution of responsibilities to the local level and experimentation with housing programmes targeting homeownership. Although the second phase of housing reforms, starting in 2000, has attempted to address the institutional and regulatory "vacuum" of the early 1990s, progress across countries has been uneven. Some of the most important challenges for the effective operation of housing institutions relate to the lack of adequate institutional capacity and resources at the local level to fulfil housing mandates. On the financial and fiscal side, despite progress in developing mortgage lending, the lack of financial transparency in housing policy and fiscal sustainability, in addition to low targeting, reflect the rudimentary nature of fiscal housing policies.

The transition in housing has exacerbated the initial differences in housing conditions across the region, leading to significant affordability constraints, deterioration of privatised housing and slum formation in post-communist cities. War-related conflicts have resulted in a housing crisis, a massive need for reconstruction and demands to provide for refugees and internally displaced people, exceeding the ability of governments to cope with such challenges. Beyond growing poverty, informality and exclusion, affordability of housing remains the fastest-growing and most pervasive challenge in the region. The market-based system is delivering better-quality housing with more variety and choice for consumers, but at a price that excludes most households from access to it. As a result, the previous shortage of housing under communism has been replaced by a shortage of affordable housing.

Although all countries continue to face similar challenges in establishing well-functioning urban housing markets, these vary widely in nature and magnitude. Given the significant differences in the region, different pathways of institutional transition affecting the diversity and operation of private and non-government institutions in the housing sector have emerged. The quality of institutions and their effectiveness is a critical dimension of this process, which depends on capacity, coordination and political structure promoting transparency and accountability. The quality dimension is also important with respect to the ability of private institutions, non-government organisations, special groups and citizens to engage in policy-making by voicing their concerns, advocating for specific policy measures and/or mobilising support for policy implementation. In the context of housing reforms, institutional and citizen engagement has focused on solving specific housing problems (access to housing, fiscal support and rent reforms), often negotiating specific benefits and public support that is not necessarily just or fair, but may reinforce the status quo or exacerbate housing inequalities. This article started with the premise that, in countries with more advanced housing reforms and established traditions for engagement and cooperation, the opportunities to "voice" opinions and to advocate for particular policy reforms would be greater. In the other countries, institutions (private and non-government) and citizens will opt for the "exit" option due to a number of constraints and general mistrust in the governance system and public institutions. This might be true, but it also depends on the nature of the housing problem and the power of strategic alliances that special interest groups might be able to mobilise. In very broad strokes, the article has reviewed a number of "voice" and "exit" options related to critical housing problems in postcommunist cities illustrating patterns of diversity, complexity and change.

The move to more democratic governance in the housing sector, coupled with political, economic and social reforms, has created a more diverse arena where different interest groups (public, private and non-governmental) interact and pursue a particular course of action. Special interest groups and strategic alliances with industry, political parties, financial interests and donor organisations have emerged with different ability to leverage public support, to "voice" their concerns and to influence policy-making and policy implementation. The research identified one particular area where housing movements have been effective in leveraging public support for access to homeownership. Most countries in the region have fiscal policies assisting homeowners through a combination of public 
provision (supply-side subsidies) and demand-based assistance (grants, interest subsidies and tax incentives). The majority of subsidies, relatively more generous at the start, have been adjusted over time in an attempt to catch up with market dynamics while maintaining a more sustainable system of housing finance. It is questionable whether scarce public funds should be used to support upper middle-income households while little government funding is directed to public rental housing or assistance to low-income households experiencing affordability problems.

Second, different special interest groups have been rather effective in resisting rent reforms, thus exacerbating housing inequality between the "haves" and the "have nots". Public rental housing essentially functions as a safety net with rents set at a fraction of market rents regardless of income. This significantly undermines investment in the sector and potentially opens the door to further privatisation because municipalities see it as a liability. Under the new subsidy regime, subsidies for new social housing have remained limited. As a result, low-income and socially marginalised households face increasing housing problems manifested in their inability to afford adequate shelter. The management of privatised housing presents a complexity of "voice" and "exit" options, increasingly mapping diverging experiences. In the privatisation aftermath, progress in developing an adequate institutional and financial framework has been limited and a handful of countries have experimented with energy efficiency and housing improvement programmes with restricted impact. Finally, the "exit" option, associated with the abandonment of the formal housing system, is a major housing problem largely attributed to the transition and is the manifestation of poverty, exclusion and informality in housing. Countries in the region experiencing informal settlement growth are grappling with the same set of systemic problems related to lack of access to affordable housing, inefficient planning and land-management systems as well as growing urban poverty, although in very different national contexts.

\section{Sasha Tsenkova}

University of Calgary, Faculty of Environmental Design, Calgary,

Canada

E-mail: tsenkova@ucalgary.ca

\section{Notes}

[1] For example, Moldova developed its housing strategy in 1998, but it was never implemented. Croatia's attempt to get its housing strategy approved failed due to changes in government, and Serbia's efforts to build consensus on social housing issues and further reforms has been jeopardised by political instability.

${ }^{[2]}$ Local governments are highly dependent on central government transfers and have limited possibilities to raise funds through local taxes (property taxes) and fees. Reliance on donor-funded projects, particularly in Serbia, Kosovo, and Bosnia and Herzegovina, makes the need for sustainable local funding more important.

${ }^{[3]}$ In terms of constraints, the growth of mortgage lending is limited by legal and administrative problems, especially those plaguing foreclosure and registration. Banks have conservative underwriting criteria due to legal uncertainties and incomplete property registration systems. Underreported income in the region and the substantial amount of informal income limit both the number of qualifying clients and the size of the loan.

${ }^{[4]}$ At the peak of the cycle in 2007, apartment prices in Riga reached EUR 7,000 per $\mathrm{m}^{2}$ in the up-market apartments in the old town, a level comparable with Stockholm, Copenhagen and Oslo. For very low-quality Soviet-type blocks in the suburbs, the market peaked at EUR 1,800 per $\mathrm{m}^{2}$. The prices in Riga then tumbled by as much as 70 to $80 \%$, reaching a low-point at the end of 2009 . This is arguably the largest property crash that the world has ever seen. Price declines in the Lithuanian and Estonian capitals were more than 50\% (European Mortgage Federation, 2010).

${ }^{[5]}$ For example, in the Czech Republic, where social rented housing is close to $20 \%$ of the stock, rents are less than $25 \%$ of the market rents. The sector is home to $10 \%$ of the most affluent households.

${ }^{[6]}$ Poland has over 600 TBS, mostly concentrated in Warsaw, Poznań and Wrocław. Financing is secured through soft loans from the National Housing Fund, a 10\% contribution from tenants and subsidised land and infrastructure provided by local municipalities (the gmina). Rents are set at $4 \%$ of construction costs (Donner, 2006).

${ }^{[7]} \mathrm{A}$ popular subsidy in Hungary was the housing construction allowance (Szocpol) introduced in the 1990s, which favoured young families with children. Generous subsidies for soft loans rapidly increased the volume of mortgage lending in 2003 and, in a desperate move to regain some sustainability in the housing system, the Hungarian government cut back the subsidies by half. In 2003 alone, an additional loan volume of HUF 800 billion (EUR 3.2 billion) resulted in an interest subsidy of HUF 80 billion (EUR 0.3 billion), or 10\%. Further changes limited the loan amount and set "normative" construction cost ceilings, but introduced tax deductibility for housing investments and a state guaranteed programme for young households allowing an LTV ratio of 80 to $90 \%$ (Donner, 2006).

${ }^{[8]}$ In Albania the target group is limited to households affected by restitution or identified as "homeless", and in Moldova public housing agencies are using state subsidies (frozen assets in unfinished housing construction) to complete the projects with additional funding from potential homeowners. In Romania, the national housing agency is building subsidised housing for young households. Serbia and Montenegro until recently maintained a communist type of housing provision through a solidarity fund.

${ }^{[9]}$ Multi-apartment panel blocks account for nearly half of the urban housing stock in Bulgaria, Romania, the Czech Republic and Moldova. They make up $70 \%$ of all housing in Bucharest, $45 \%$ in Sofia, 30\% in Budapest and 20\% in Ljubljana (Tsenkova \& French, 2011).

${ }^{[10]}$ Households in Hungary spend approximately $20 \%$ of their incomes on utility costs, of which a major part is heating expenditures. For lower-income categories, this share increases to 27 to $37 \%$ of their incomes (European Commission, 2010).

${ }^{[11]}$ Some estimates by the United Nations Human Settlements Programme (2007) indicate that about $10 \%$ of the urban population lives in slum conditions without access to basic services and/or in overcrowded dwellings (30\% for Moldova and 19\% in Romania, Bosnia and Herzegovina, Croatia and Macedonia).

${ }^{[12]}$ In Serbia around $70 \%$ of Roma households reportedly live in dwellings with no water connection, over $80 \%$ with no sewerage and $65 \%$ 
in illegally built settlements. In Montenegro, 32\% of the Roma live in collective centres and $47 \%$ live in shanties, and $45 \%$ lack plumbing and running water at home (World Bank, 2005).

\section{References}

Angel, S. (2000) Housing policy matters - A global analysis. New York, Oxford University Press.

Buckley, R. \& Tsenkova, S. (2001) Housing market systems in reforming socialist economies: Comparative indicators of performance and policy. European Housing Policy, 1(2), pp. 1-34.

Donner, C. (2006) Housing policies in central eastern Europe: Czech Republic / Hungary / Poland / Slovenia / Slovakia. Vienna, Donner.

Duncan, J. (2005) From Budapest to Bishkek: Mapping the root of poverty housing. Bratislava, Habitat for Humanity Europe and Central Asia.

European Bank for Reconstruction and Development (2009) Transition report 2009. London.

European Commission (2010) The social situation in the European Union 2009. Brussels.

European Mortgage Federation (2010) HYPOSTAT 2009: A review of Europe's mortgage and housing markets. Brussels.

Gruis, V., Tsenkova, S. \& Niebor, N. (eds.) (2009) Managing privatised housing: International perspectives. Oxford, Blackwell. DOI: 10.1002/9781444322613

Hegedüs, J., Lux, M. \& Teller, N. (2013) Social housing in transition countries. Arlington, Taylor \& Francis.

Hegedüs, J., Mayo, S. \& Tosics, I. (1996) Transition of the housing sector in the east central European countries. Review of Urban and Regional Development Studies, 8(2), pp. 101-136.

DOI: 10.1111/j.1467-940X.1996.tb00113.x

Hegedüs, J. \& Struyk, R. (eds.) (2006) Housing finance: New and old models in central Europe, Russia, and Kazakhstan. Budapest, Open Society, Local Government and Public Service Reform Initiative.

Hirschman, A. (1970) Exit, voice, and loyalty: Responses to decline in firms, organizations, and states. Cambridge, MA, Harvard University Press.

Internal Displacement Monitoring Centre (2007) Global monitoring project. Geneva.

Jenkins, J. (1983) Resource mobilization theory and the study of social movements. Annual Review of Sociology, 9, pp. 527-553.

DOI: 10.1146/annurev.so.09.080183.002523

Kušar, S. (2012) Selected spatial effects of the global financial and economic crisis in Ljubljana, Slovenia. Urbani izziv, 23(2), pp. 112-120. DOI: 10.5379/urbani-izziv-en-2012-23-02-004

Leckie, S. (2002) Regional housing issues profile, implementing housing rights in south east Europe. Nairobi, United Nations Human Settlements Programmes.

Lowe, S. \& Tsenkova, S. (eds.) Housing change in central and eastern Europe: Integration or fragmentation. Aldershot, Ashgate Publishing Limited.

Mavromatidis, L. E. \& Mavromatidi, A. (2012) Reinventing the doubt of the icon: A virtual case study in a post-Soviet country's capital. Urbani izziv, 23(2), pp. 79-92. DOI: 10.5379/urbani-izziv-en-2012-23-02-001

Morris, A. \& Mueller, C. (1995) (eds.) Frontiers in social movement theory. New Haven, Yale University Press.
Olson, M. (1965) The logic of collective action. Cambridge, MA, Harvard University Press.

Palacin, J. \& Shelburne, R. (2005) The private housing market in eastern Europe and the CIS. Geneva, United Nations Economic Commission for Europe.

Pickvance, C. (2001) Inaction, individual action and collective action responses to housing dissatisfaction: A comparative study of Budapest and Moscow. Political Opportunities, Social Movements and Democratization, 23, pp. 179-206.

Pickvance, C., Pickvance-Lang, K. \& Manning, N. (1997) Environmental and housing movements. Grassroots experience in Hungary, Russia and Estonia. Avebury, Aldershot.

Puzanov, A. (2009) Housing policy reforms and market responses in Russia. Moscow, Institute of Urban Economics.

Registra, Analystas and Imantra (2005) Housing finance in Croatia. Washington, DC

Royal Institution of Chartered Surveyors (2010) European housing review 2010. Brussels.

Sendi, R. (2010) Housing bubble burst or credit crunch effect? Slovenia's housing market. Urbani izziv, 21(2), pp. 96-105.

DOI: 10.5379/urbani-izziv-en-2010-21-02-003

Sendi, R. (2013) The low housing standard in Slovenia: Low purchasing power as an eternal excuse. Urbani izziv, 24(1), pp. 107-124. DOI: 10.5379/urbani-izziv-en-2013-24-01-002

Stefanovska, J. \& Koželj, J. (2012) Urban planning and transitional development issues: The case of Skopje, Macedonia. Urbani izziv, 23(1), pp. 91-100. DOI: 10.5379/urbani-izziv-en-2012-23-01-002

Struyk, R. (ed.) (2000) Homeownership and housing finance policy in the former Soviet bloc: Costly populism. Washington DC, Urban Institute Press.

Tsenkova, S. (2005) Trends and progress in housing reforms in south east Europe. Paris, Council of Europe Development Bank.

Tsenkova, S. (2006) Beyond transitions: Understanding urban change in post-socialist cities. In: Tsenkova, S. \& Nedovic-Budic, Z. (eds.) The urban mosaic of post-socialist Europe, pp. 21-50. Heidelberg, Springer-Verlag. DOI: 10.1007/3-7908-1727-9_2

Tsenkova, S. (2009) Housing reforms in post-socialist Europe. Lost in transition. Heidelberg, Springer-Verlag. DOI: 10.1007/978-3-7908-2115-4

Tsenkova, S. (2010) Informal settlements in post-communist cities: Diversity factors and patterns. Urbani izziv, 21(2), pp. 73-84. DOI: 10.5379/urbani-izziv-en-2010-21-02-001

Tsenkova, S. (2011) Venturing into unknown territory: Strategic spatial planning in post-communist cities. Urbani izziv, 22(1), pp. 83-99. DOI: 10.5379/urbani-izziv-en-2011-22-01-001

Tsenkova, S. (2012a) Housing management institutions: Post-socialist. In: Smith, S., Elsinga, M., O'Mahony, L., Eng, S., Wachter, S. \& Ronald, R. (eds.). International encyclopedia of housing \& home, volume 5, pp. 420 426. Oxford, Elsevier. DOI: 10.1016/B978-0-08-047163-1.00473-2

Tsenkova, S. (2012b) Urban planning and informal cities in south-eastern Europe. Journal of Architectural and Planning Research, 29(4), pp. 292-305.

Tsenkova, S. \& French, M. (2011) Affordable land and housing in Europe and North America. Nairobi, United Nations Human Settlements Programmes.

Tsenkova, S. \& Turner, B. (2004) The future of social housing in eastern Europe: Reforms in Latvia and Ukraine. European Journal of Housing Policy, 4(2), pp. 133-149. DOI: 10.1080/1461671042000269001 
United Nations Economic Commission for Europe (1997) Human settlement trends in central and eastern Europe. Geneva.

United Nations Economic Commission for Europe (2003) Country profiles on housing: Albania. Geneva.

United Nations Economic Commission for Europe (2006) Country profiles on housing: Serbia and Montenegro. Geneva.

United Nations Human Settlements Programmes (2007) State of the World Cities Report 2006/07. London, Earthscan.

Vienna Declaration (2004) Vienna declaration on national and regional policy and programmes regarding informal settlements in South Eastern Europe. Ministerial Conference on Informal Settlements in South Eastern Europe, 28 Sep.-1 Oct. 2004, Vienna, Austria.

World Bank (2005) Rental choice and housing policy realignment in transition: Post-privatization challenges in the Europe and Central Asia region. Washington, DC.

World Bank (2006) Thirty years of World Bank shelter lending: What have we learned? Washington, DC. 